University of Nebraska - Lincoln

DigitalCommons@University of Nebraska - Lincoln

U.S. Environmental Protection Agency Papers

U.S. Environmental Protection Agency

2016

\title{
A comparison between 2010 and 2006 air quality and meteorological conditions, and emissions and boundary conditions used in simulations of the AQMEII-2 North American domain
}

Till E. Stoeckenius

ENVIRON International Corp., till@environcorp.com

Christian Hogrefe

U.S. Environmental Protection Agency

Justin Zagunis

ENVIRON International Corp.

Timonthy M. Sturtz

ENVIRON International Corp.

Benjamin Wells

U.S. Environmental Protection Agency

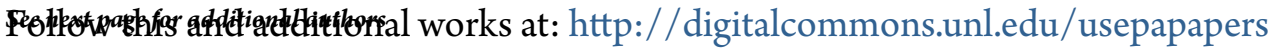

Part of the Earth Sciences Commons, Environmental Health and Protection Commons, Environmental Monitoring Commons, and the Other Environmental Sciences Commons

Stoeckenius, Till E.; Hogrefe, Christian; Zagunis, Justin; Sturtz, Timonthy M.; Wells, Benjamin; and Sakulyanontvittaya, Tanarit, "A comparison between 2010 and 2006 air quality and meteorological conditions, and emissions and boundary conditions used in simulations of the AQMEII-2 North American domain" (2016). U.S. Environmental Protection Agency Papers. 250.

http://digitalcommons.unl.edu/usepapapers/250

This Article is brought to you for free and open access by the U.S. Environmental Protection Agency at DigitalCommons@University of Nebraska Lincoln. It has been accepted for inclusion in U.S. Environmental Protection Agency Papers by an authorized administrator of DigitalCommons@University of Nebraska - Lincoln. 
Authors

Till E. Stoeckenius, Christian Hogrefe, Justin Zagunis, Timonthy M. Sturtz, Benjamin Wells, and Tanarit Sakulyanontvittaya 


\title{
A comparison between 2010 and 2006 air quality and meteorological conditions, and emissions and boundary conditions used in simulations of the AQMEII-2 North American domain
}

\author{
Till E. Stoeckenius ${ }^{a}{ }^{*}$, Christian Hogrefe ${ }^{b}$, Justin Zagunis ${ }^{a}$, Timothy M. Sturtz ${ }^{\text {a }}$, \\ Benjamin Wells ${ }^{\mathrm{b}}$, Tanarit Sakulyanontvittaya ${ }^{\mathrm{a}}$ \\ ${ }^{\text {a }}$ ENVIRON International Corp., Novato, CA, USA \\ ${ }^{\mathrm{b}}$ U.S. Environmental Protection Agency, Research Triangle Park, NC, USA
}

\section{H I G H L I G H T S}

- We compare emissions, meteorology and air quality over N. America in 2006 and 2010.

- Results provide context for evaluation of regional models under AQMEII-2 initiative.

- Reductions in emissions did not always result in reduced concentrations.

- Ozone higher in 2010 than in 2006 due to more favorable meteorological conditions.

\section{A R T I C L E I N F O}

\section{Article history:}

Received 31 May 2014

Received in revised form

12 February 2015

Accepted 15 February 2015

Available online 16 February 2015

\section{Keywords:}

\section{AQMEII}

Air quality - meteorology interactions

Emission trends

Ozone trends

Synoptic types

\begin{abstract}
A B S T R A C T
Several participants in Phase 2 of the Air Quality Model Evaluation International Initiative (AQMEII-2) who are applying coupled models to the North American domain are comparing model results for two years, 2006 and 2010, with the goal of performing dynamic model evaluation. From a modeling perspective, the differences of interest are the large reductions in domain total emissions of $\mathrm{NO}_{\mathrm{x}}(21 \%)$ and $\mathrm{SO}_{2}$ (37\%) from 2006 to 2010 and significant differences in meteorological conditions between these two years. The emission reductions occurred mostly in the eastern U.S, with some reduction in emissions from western wildfires in 2010. Differences in meteorological conditions both confound the impact of emission reductions on ambient air quality and provide an opportunity to examine how models respond to changing meteorology. This study is aimed at documenting changes in emissions, modeled large-scale background concentrations used as boundary conditions for the regional models, and observed meteorology and air quality to provide a context for the dynamic model evaluation studies performed within AQMEII-2. In addition to warmer summer temperatures, conditions in the eastern U.S. summer of 2010 were characterized by less precipitation than in 2006, while western portions of the U.S. and Canada were much cooler in 2010 due to a strengthening of the thermal trough over the Southwest and associated onshore flow. Summer ozone levels in many portions of the Northeast and Midwest were largely unchanged in 2010 despite reductions in precursor emissions. Normalization of the ozone trend, to account for differences in meteorological conditions, including warmer summer temperatures in 2010 , shows that the emission reductions would have resulted in lower ozone levels at these locations if not for the countervailing influence of meteorological conditions. Winter mean surface temperatures were generally above average in 2006 whereas below average temperatures were noted in the Southeast and northern plains in 2010, consistent with a greater frequency of cold arctic air outbreaks. In general, changes in observed air quality as measured at U.S. monitoring sites appear to be consistent with differences in emissions and meteorological conditions between 2006 and 2010. Two potential inconsistencies were noted which warrant further investigation: 1) an increase in particulate nitrate during the winter in the Midwest despite lower emissions of $\mathrm{NO}_{\mathrm{x}}$ and 2) lower than expected $\mathrm{SO}_{2}$ reductions in the Southeast during the winter.
\end{abstract}

(c) 2015 Elsevier Ltd. All rights reserved.

\footnotetext{
* Corresponding author. 773 San Marin Dr., Suite 2115, Novato, CA 94998, USA.

E-mail address: till@environcorp.com (T.E. Stoeckenius).
} 


\section{Introduction}

Development of accurate models for simulating atmospheric trace gas composition is a key component of an effective air quality management program. The Air Quality Model Evaluation International Initiative (AQMEII) was developed to fulfill the need to both better understand uncertainties in regional-scale model predictions and to foster continued model improvement by providing a collaborative, cross-border platform for model development and evaluation in North America and Europe (Galmarini and Rao, 2011).

While Phase 1 of the AQMEII focused on evaluation of offline air quality models forced by results from separately executed meteorological models (Galmarini et al., 2012), Phase 2 of AQMEII (AQMEII-2) focused on evaluation of online-coupled models capable of simulating feedbacks between atmospheric trace gas composition and meteorological conditions. AQMEII-2 included the option for participants to evaluate model performance for two individual calendar years: 2006 and 2010. As emissions from anthropogenic sources were reduced substantially during the interval between these two years, comparing model results for 2006 with 2010 provides an opportunity to examine the ability of coupled models to simulate the impact of emission reductions on both air quality and the potential feedbacks from air quality - to meteorology. More generally, comparing model predictions across multiple years allows dynamic model evaluation, i.e. assessing the models' ability to respond to changes in forcing factors (Dennis et al., 2010).

Regional scale online-coupled models are driven by estimates of trace gas and particulate matter emissions and meteorological and chemical boundary and initial conditions. Changes in these inputs between 2006 and 2010 drive the 2006-2010 differences in predicted air quality. It is therefore important to understand observed changes in air quality and meteorological conditions between the two years in order to better understand the model results and

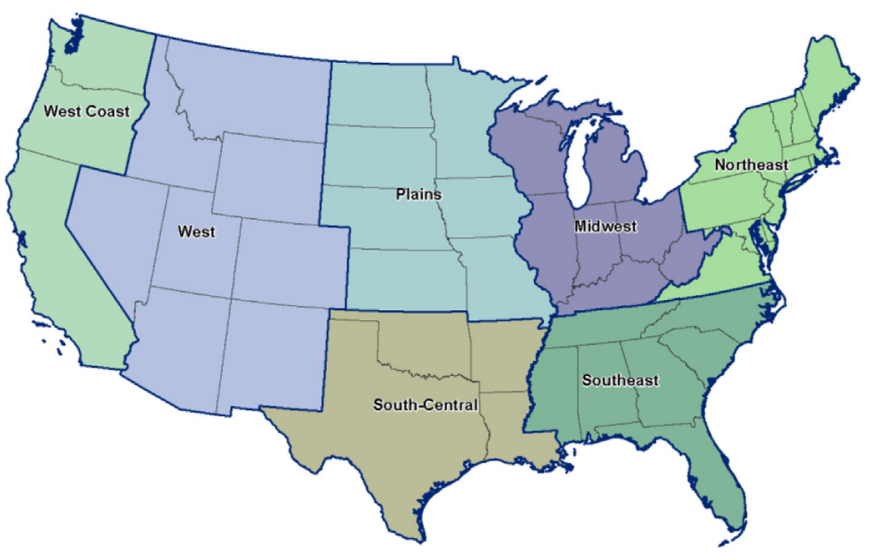

Fig. 2. U.S. sub-regions used to summarize emissions and air quality.

provide a context for dynamic model evaluation studies. We present here a summary of the key observed meteorological and air quality features of 2006 and 2010 together with a summary of the emission inventories and large-scale modeled air quality fields

Table 1

Fractional changes in annual U.S. emissions [(2010-2006)/2006] by sub-region (non-U.S. emissions in the North America modeling domain are unchanged).

\begin{tabular}{lrrrrrrr}
\hline & $\mathrm{CO}$ & $\mathrm{NH}_{3}$ & $\mathrm{NO}_{\mathrm{x}}$ & $\mathrm{PM}_{10}$ & $\mathrm{PM}_{2.5}$ & $\mathrm{SO}_{2}$ & $\mathrm{VOC}$ \\
\hline Midwest & $-20 \%$ & $1 \%$ & $-25 \%$ & $5 \%$ & $7 \%$ & $-36 \%$ & $-7 \%$ \\
Northeast & $-25 \%$ & $-1 \%$ & $-22 \%$ & $-1 \%$ & $-3 \%$ & $-44 \%$ & $-11 \%$ \\
Plains & $-6 \%$ & $1 \%$ & $-18 \%$ & $-5 \%$ & $10 \%$ & $-17 \%$ & $3 \%$ \\
South-Central & $-15 \%$ & $1 \%$ & $-11 \%$ & $1 \%$ & $4 \%$ & $-11 \%$ & $-2 \%$ \\
Southeast & $-23 \%$ & $0 \%$ & $-25 \%$ & $0 \%$ & $0 \%$ & $-52 \%$ & $-9 \%$ \\
West & $-50 \%$ & $-16 \%$ & $-19 \%$ & $-22 \%$ & $-46 \%$ & $-26 \%$ & $-36 \%$ \\
West Coast & $-37 \%$ & $-13 \%$ & $-25 \%$ & $-36 \%$ & $-50 \%$ & $-25 \%$ & $-33 \%$ \\
TOTAL: & $-26 \%$ & $-3 \%$ & $-21 \%$ & $-9 \%$ & $-14 \%$ & $-37 \%$ & $-13 \%$ \\
\hline
\end{tabular}
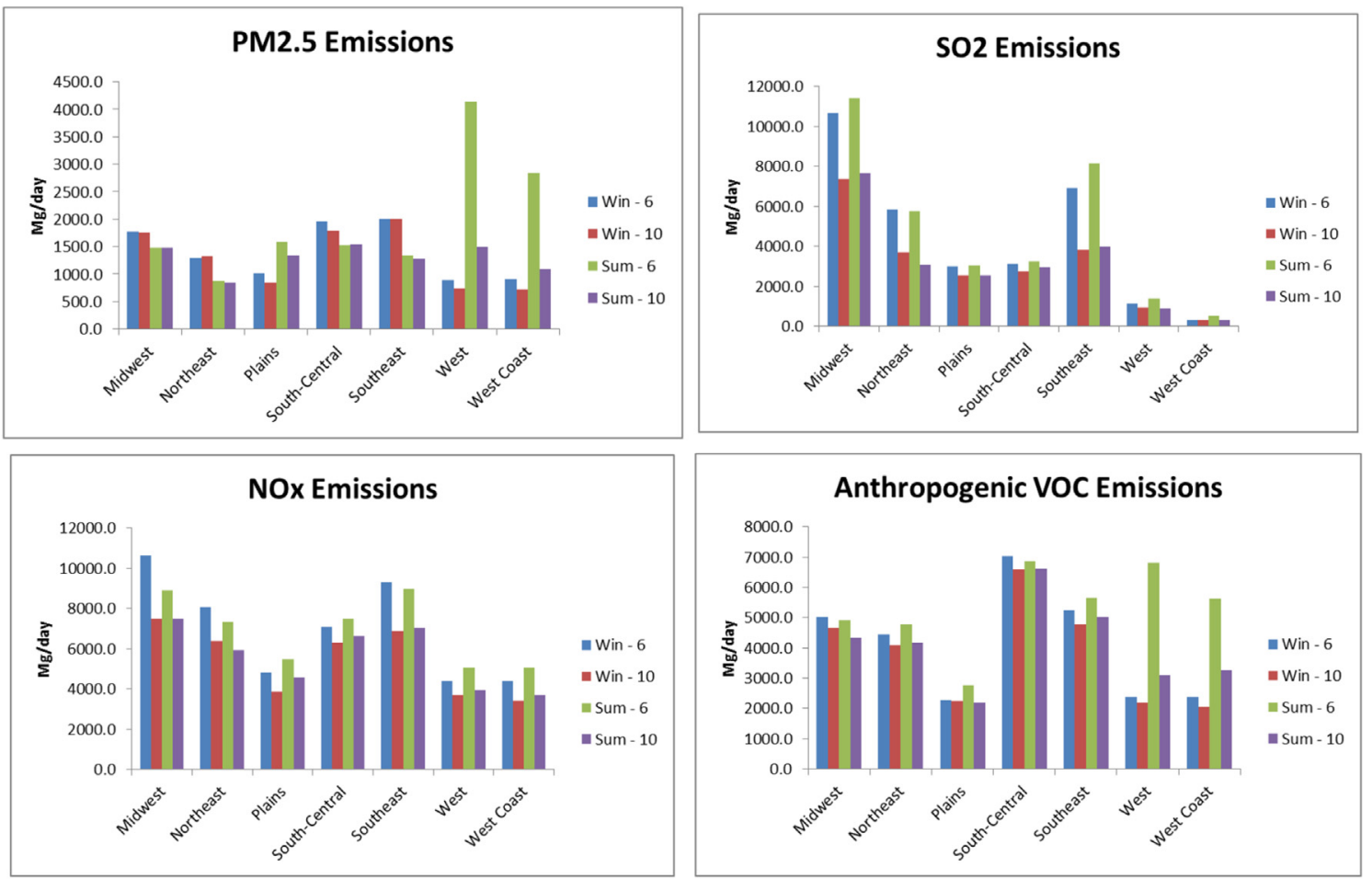

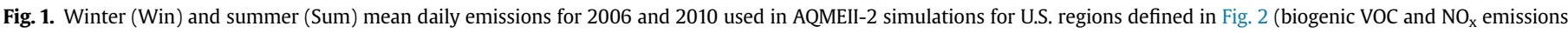
are not included). 
Table 2

Reductions in $\mathrm{NO}_{\mathrm{x}}$ emissions by 2010 relative to 2006 levels for U.S. regions (CEMS point source emissions values obtained from continuous emission monitoring data).

\begin{tabular}{|c|c|c|c|c|}
\hline \multirow{2}{*}{$\frac{\mathrm{NO}_{\mathrm{x}}}{\% \text { change }}$} & \multicolumn{2}{|c|}{ CEMS point sources } & \multicolumn{2}{|c|}{ All sources } \\
\hline & Winter & Summer & Winter & Summer \\
\hline Midwest & $-54 \%$ & $-7 \%$ & $-30 \%$ & $-16 \%$ \\
\hline Northeast & $-37 \%$ & $-6 \%$ & $-21 \%$ & $-19 \%$ \\
\hline Plains & $-35 \%$ & $-29 \%$ & $-20 \%$ & $-17 \%$ \\
\hline South-Central & $-8 \%$ & $-13 \%$ & $-11 \%$ & $-11 \%$ \\
\hline Southeast & $-55 \%$ & $-36 \%$ & $-26 \%$ & $-22 \%$ \\
\hline West & $-23 \%$ & $-26 \%$ & $-16 \%$ & $-22 \%$ \\
\hline West Coast & $26 \%$ & $1 \%$ & $-22 \%$ & $-27 \%$ \\
\hline
\end{tabular}

used to specify chemical boundary conditions used by all AQMEII-2 participants. As modeling of both 2006 and 2010 has thus far only been conducted by AQMEII-2 participants for the North American domain, our analysis focusses on North America. Moreover, as discussed in the next section, year specific emission information for 2006 and 2010 was available only for the U.S., therefore the analysis of emissions and observed air quality is limited to the U.S. Comparisons of observed meteorological and air quality conditions with model predictions are not included in this paper but are the subject of several companion papers (Campbell et al., 2015; Hogrefe et al.,
2015; Wang et al., 2015); the current study provides context for these studies.

\section{Materials and methods}

\subsection{Air quality}

Air quality observations from all available monitoring sites in the U.S. for 2006 and 2010 were extracted from the U.S. Environmental Protection Agency (EPA) Air Quality System (AQS) and processed into seasonal means by Hogrefe et al. (2015). Seasons were defined by month as follows: winter (December-February), spring (March-May), summer (June-August) and fall (September-November). Monitoring data from sites in Canada and Mexico were not included in this study because year specific emissions for 2006 and 2010 were only available for the U.S. (Section 2.2) and the resulting air quality impacts are expected to be most pronounced at U.S. monitoring locations. Daily maximum running 8-hour average ozone concentrations (MDA8O3) were extracted from AQS and averaged over each season. Sites with less than 75\% valid MDA8O3 for a season were excluded from the analysis. Daily average $\mathrm{PM}_{2.5}$ concentrations were obtained from both 24-hour averages of continuous $\mathrm{PM}_{2.5}$ monitors which report hourly data and 24-hour
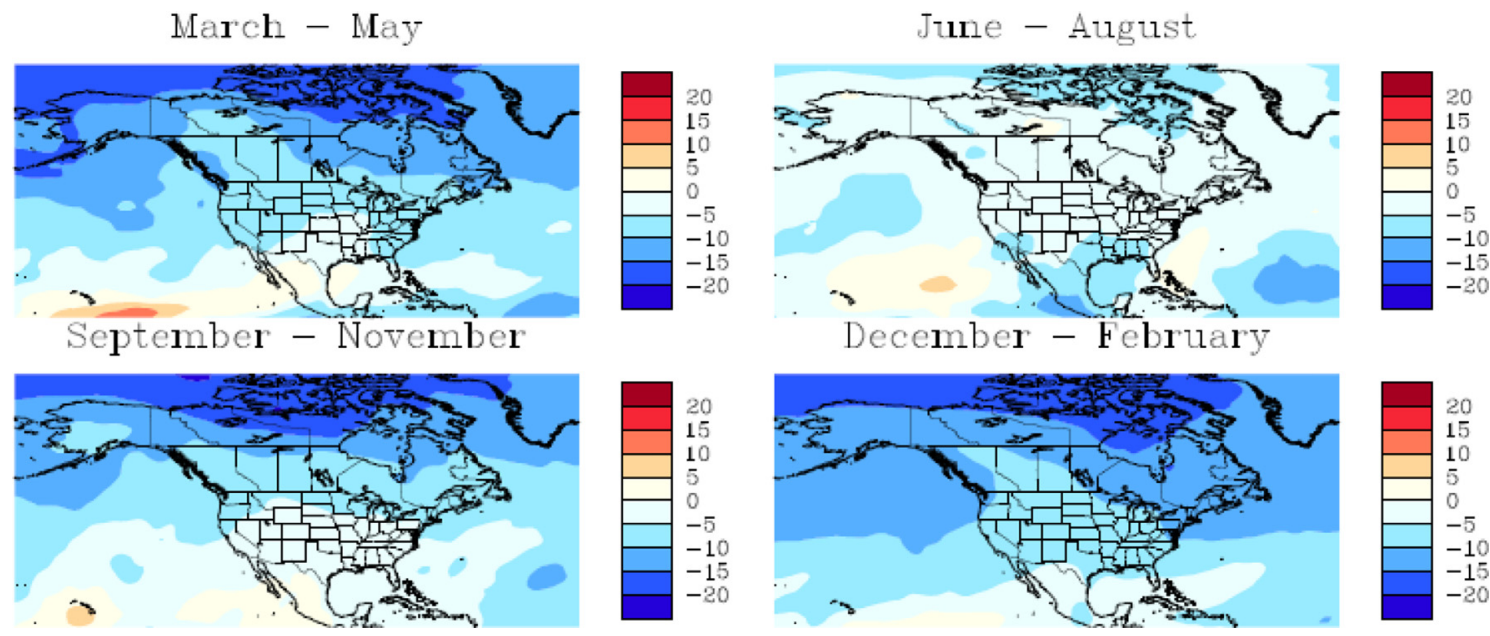

Fig. 3. Difference (2010-2006) in seasonal mean mid-tropospheric ( $750 \mathrm{mb})$ ozone concentrations (ppb) as predicted by IFS-MOZART.
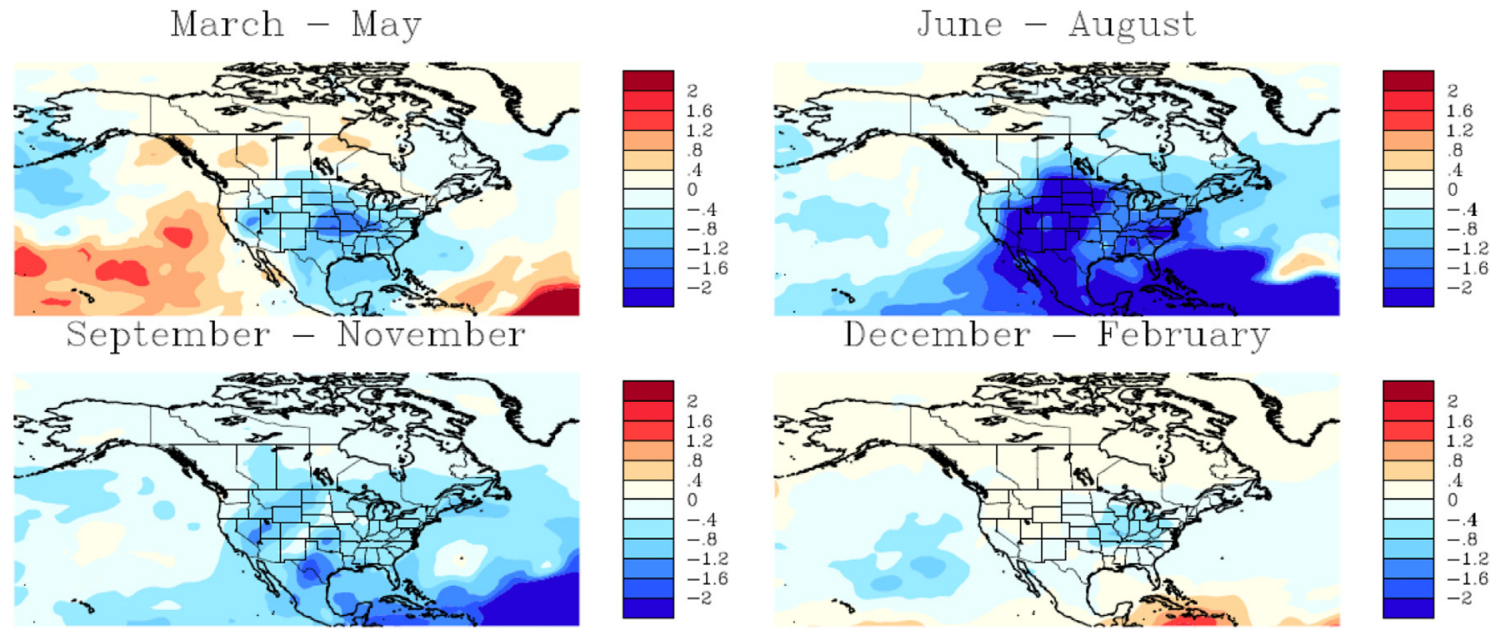

December - February
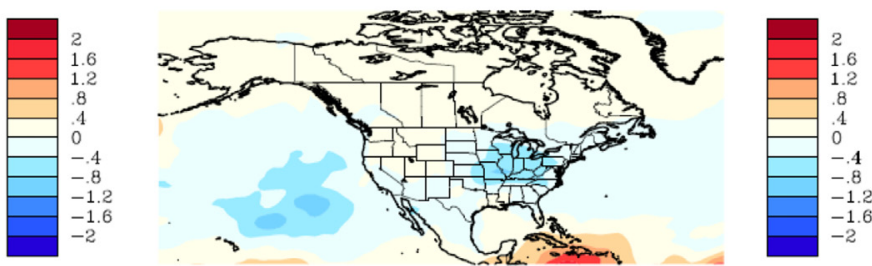

Fig. 4. Difference (2010-2006) in seasonal mean mid-tropospheric $(\sim 750 \mathrm{mb})$ fine dust concentrations $\left(\mu \mathrm{g} / \mathrm{m}^{3}\right)$ as predicted by IFS-MOZART. 
integrated (filter-based) $\mathrm{PM}_{2.5}$ measurements; the daily averages were then averaged over each season. Seasonal averages based on $\mathrm{PM}_{2.5}$ sites which report hourly data were excluded if less than $75 \%$ of hours had valid data, $\mathrm{PM}_{2.5}$ sites with either daily or 1-in-3 day sampling schedules were excluded if fewer than $75 \%$ of schedule sample days had valid daily averages; $\mathrm{PM}_{2.5}$ sites with 1-in-6 day sampling schedules were excluded if fewer than 15 valid samples were reported for the season. Hourly $\mathrm{SO}_{2}$ data were averaged over each season and sites with less than $75 \%$ valid hourly values were removed from the analysis.

\subsection{Emissions}

Gridded, hourly, model-ready emissions for 7 species $\left(\mathrm{CO}, \mathrm{NH}_{3}\right.$, $\mathrm{NO}_{\mathrm{x}}, \mathrm{PM}_{10}, \mathrm{PM}_{2.5}, \mathrm{SO}_{2}, \mathrm{VOC}$ ) and 20 major anthropogenic source categories were extracted from data files used by all AQMEII-2 North American domain participants (Pouliot et al., 2015), processed into seasonal totals, and then divided by the number of days in each season to obtain daily average emissions by season for each U.S. state and for Canada and Mexico. For model grid cells which straddle state or country boundaries, non-point source emissions were assigned to the state or country accounting for the majority of the grid cell area. Given the relatively small $12 \mathrm{~km}$ horizontal grid resolution, the resulting emission allocation errors are negligible. Point sources were assigned to states and countries based on their actual location.

Biogenic and geogenic emissions, which can have significant impacts on air quality, were not provided as a priori emission inputs, rather AQMEII-2 participants were expected to derive the emissions using coupled models. In-line calculations of these emissions generally differ from one model to the next, but were not included here given our focus on characterizing forcings common to all models (i.e., anthropogenic emissions and large-scale background concentrations used to specify chemical boundary conditions) as well as observed meteorological and air quality conditions. We note, however, that the bio- and geogenic emissions derived within the coupled models were likely influenced by the 2006-2010 differences in meteorological conditions.

\subsection{Meteorology}

Meteorological data were obtained from two sources: 1) gridded (approximately $12 \mathrm{~km}$ horizontal resolution) 2006 and 2010 seasonal means for key surface and upper air parameters and cumulative precipitation data were obtained from initialization fields for the North American Model via the NOAA NOMADS server (Rutledge et al., 2006) and 2) seasonal anomalies were obtained from the NCEP/NCAR 40-year Reanalysis data (Kalnay and Coauthors, 1996) via the NOAA/ESRL Physical Sciences Division, Boulder Colorado from their Web site at http://www.esrl.noaa.gov/psd/.

\section{Results}

\subsection{Emissions}

Modeling of the North American domain by AQMEII-2 participants used emission inventories for 2006 and 2010 derived from U.S. EPA's 2008 emissions modeling platform with year-specific adjustments to activity levels and emission factors for on-road and off-road mobile sources, use of year-specific continuous

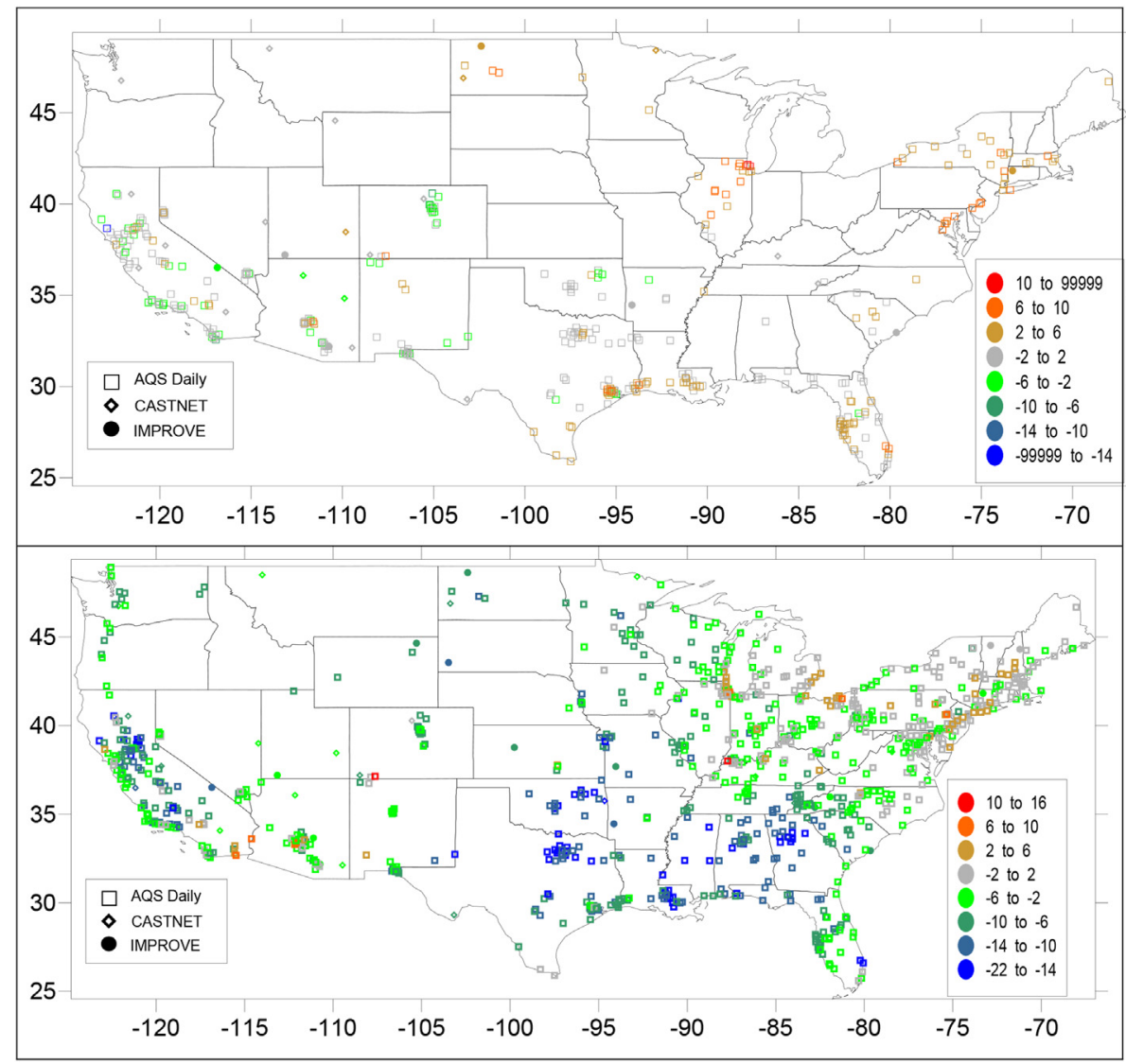

Fig. 5. Difference (2010-2006) in seasonal mean MDA803 ozone concentrations (ppb) during winter (top) and summer (bottom) at U.S. monitoring sites. 
emissions monitoring systems (CEMS) data for the large point sources where CEMS data were available, and year-specific fire emissions estimates. Updated estimates of Canadian emissions and Mexican emissions developed for 2006 were used without adjustment in the 2010 inventory (Pouliot et al., 2015). Thus the only differences between the 2006 and 2010 modeling inventories are changes to mobile sources, CEMS point sources and fire emissions in the U.S. For this reason, the following discussion of emission changes is limited to U.S. emissions and the subsequent discussion of observed differences in air quality is focused on the U.S as well. Biogenic and wind-blown dust emissions were calculated on-line by each modeling group and were not available for use in this study.

Significant reductions in emissions from electric power generation occurred between 2006 and 2010 in the eastern U.S. as reflected in summaries of total U.S. sub-regional emissions (Fig. 1; sub-region definitions in Fig. 2). Seasonal reductions of $31 \%-52 \%$ occurred in $\mathrm{SO}_{2}$ and $22 \%-15 \%$ in $\mathrm{NO}_{\mathrm{x}}$ in the Midwest, Northeast, and Southeast (Table 1). $\mathrm{SO}_{2}$ emissions also decreased in other subregions but by smaller amounts. Comparable $\mathrm{NO}_{\mathrm{x}}$ reductions occurred in other sub-regions except for a smaller (11\%) reduction in the South-Central sub-region. $\mathrm{NO}_{\mathrm{x}}$ reductions varied seasonally for the large sources with CEMS (mostly electric utilities) as shown in Table 2. Utilities in the Midwest and Northeast already had significant controls in effect during the summer season by 2006 and only minor additional summer season reductions occurred by 2010 whereas large reductions occurred year-round between 2006 and 2010 in the Southeast where summer season controls had not previously been widely applied. Winter season $\mathrm{NO}_{\mathrm{x}}$ reductions for large point sources with CEMS were more comparable across these regions, reflecting the expansion of ozone focused summer season
$\mathrm{NO}_{\mathrm{x}}$ controls to year round controls aimed at reducing $\mathrm{PM}_{2.5}$ under the Clean Air Interstate Rule (CAIR). Nevertheless, total $\mathrm{NO}_{\mathrm{x}}$ emission reductions were similar in winter and summer in the Northeast as the seasonal difference in the utility emission reductions is diluted by large but seasonally invariant reductions in mobile sources and the (assumed) 0\% change in area source emissions.

$\mathrm{PM}_{2.5}$ emissions showed little change overall except in the western sub-regions. Both PM and anthropogenic VOC emissions were strongly elevated in the summer of 2006 in the West due to major wildfires: in the 13 western states, 6.7 million acres burned in 2006 as compared to 1.5 million acres in 2010 (NIFC, 2014). Apart from the influence of fires, there were small reductions in on-road and off-road mobile source VOC emissions.

\subsection{Boundary conditions}

Chemical boundary conditions for a number of gas phase species as well dust, elemental carbon, organic carbon, and sulfate used in the coupled model simulations performed by each AQMEII-2 participating group were derived from global fields generated under the MACC project using the IFS-MOZART modeling system which also incorporated satellite data for selected variables (Inness et al., 2013). Boundary conditions (BCs) can have a significant impact on regional model predictions (Schere et al., 2012) and therefore differences between 2006 and 2010 in IFS-MOZART simulations over North America, in particular over inflow regions, can be expected to significantly contribute to differences in regional model predictions. While quantitative estimates of the impact of changed BC between 2006 and 2010 on changes in total pollutant loadings in the North America simulations were not available at the time of this analysis, Hogrefe et al. (2015) present a sensitivity study

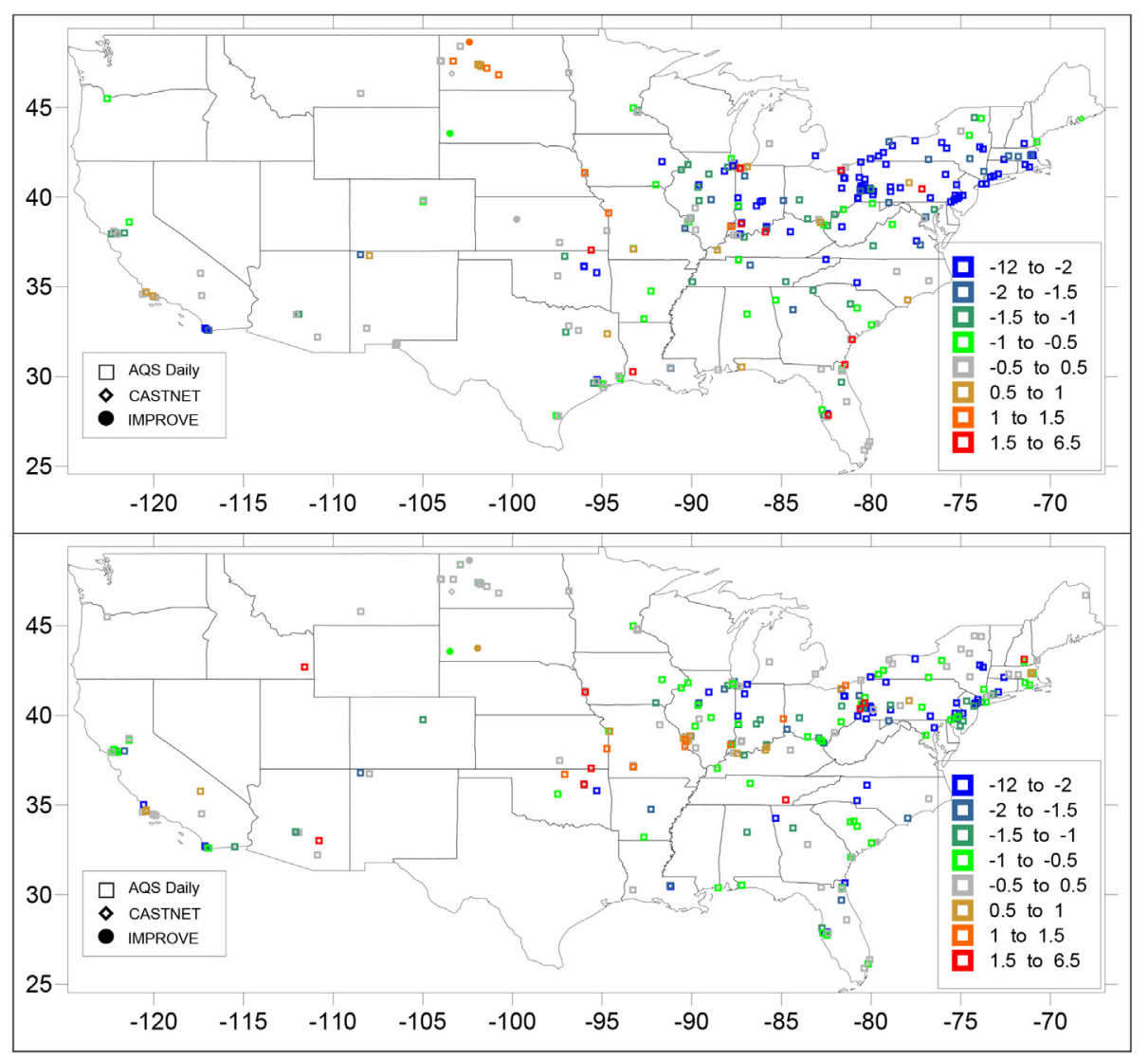

Fig. 6. Change (2010-2006) in seasonal mean $\mathrm{SO}_{2}$ concentration (ppb) during winter (top) and summer (bottom) at U.S. monitoring sites. 
towards changed BC for January and July 2006 while Giordano et al. (2015) compare pollutant concentrations simulated by IFSMOZART and the AQMEII-2 regional models for 2010 to estimate the degree to which $\mathrm{BC}$ affect regional simulations. In this study, we complement their analyses by presenting comparisons of IFSMOZART seasonal mean mid-tropospheric predictions over North America to gain some insight into the likely influence of large-scale background changes between 2006 and 2010 on the regional model predictions based on the assumption that mid-tropospheric conditions are roughly indicative of impacts of BC tendencies on concentrations at the surface.

IFS-MOZART mid-tropospheric seasonal mean ozone is generally lower in 2010 as compared to 2006; the decreases are smaller during the summer (generally less than $5 \mathrm{ppb}$ though as large as $10 \mathrm{ppb}$ in some inflow regions over the Pacific, Canada and the Gulf of Mexico) but larger during the rest of the year with winter and spring decreases reaching 10-20 ppb over the Pacific and Canada (Fig. 3). Mid-tropospheric fine dust was predicted by IFS-MOZART to be significantly lower during the summer and fall of 2010 as compared to 2006 but during spring dust levels over the Pacific (which are typically transported westward towards the U.S.) were higher in 2010, potentially indicating greater influx of fine dust over the North American west coast. Spring dust levels over the interior west and eastern U.S. were nevertheless lower, suggesting reductions in windblown dust emissions simulated by the IFSMOZART system over most of the U.S. in 2010 outweighed any influence of long-range transport (Fig. 4). Examination of seasonal mean IFS-MOZART fine dust patterns in 2006 and 2010 (not shown) indicates that the pattern of 2010-2006 differences seen in Fig. 4 is due primarily to the presence of a more concentrated Asian dust plume stretching further west across the Pacific coupled with less dusty conditions over the Great Plains in 2010 presumably due to meteorological conditions less conducive to the formation of windblown dust. The summer mean IFS-MOZART fine dust maps are also suggestive of less African dust reaching the U.S. during the summer of 2010. The spring spatial pattern of mid-tropospheric sulfate aerosol 2010-2006 differences predicted by IFS-MOZART (Fig. S3) also shows enhanced transport across the Pacific in 2010 relative to 2006, consistent with a meteorological regime more favorable to eastward transport in 2010 although higher emissions of both sulfate and dust in Asia may have been a contributing factor. Organic matter and fine sea salt 2010-2006 differences in the IFSMOZART fields were small except for localized large decreases in summer organic matter in western fire areas (not shown).

\subsection{Observed air quality}

Significant differences are evident in observed air quality conditions in the U.S. between 2010 and 2006. Summer mean MDA8O3 concentrations were generally lower in 2010 than in 2006 except for the Northeast and upper Midwest where there were increases at many sites along the Washington to Boston urban corridor and in the Chicago area, and near zero ( $\pm 2 \mathrm{ppb}$ ) changes away from the major urban areas (Fig. 5). Increases also occurred in extreme southeastern California, Phoenix, and at one site in southwestern Colorado. Similar spatial patterns are seen in 2010-2006 differences in the annual 4th highest MDA803, the contiguous three year average of which is the summary statistic referenced in the U.S. EPA's primary (health-based) National Ambient Air Quality Standard (Fig. S1). Winter mean MDA803 concentration differences (2010-2006) are mixed: increases were observed at most eastern urban sites while a combination of increases and decreases

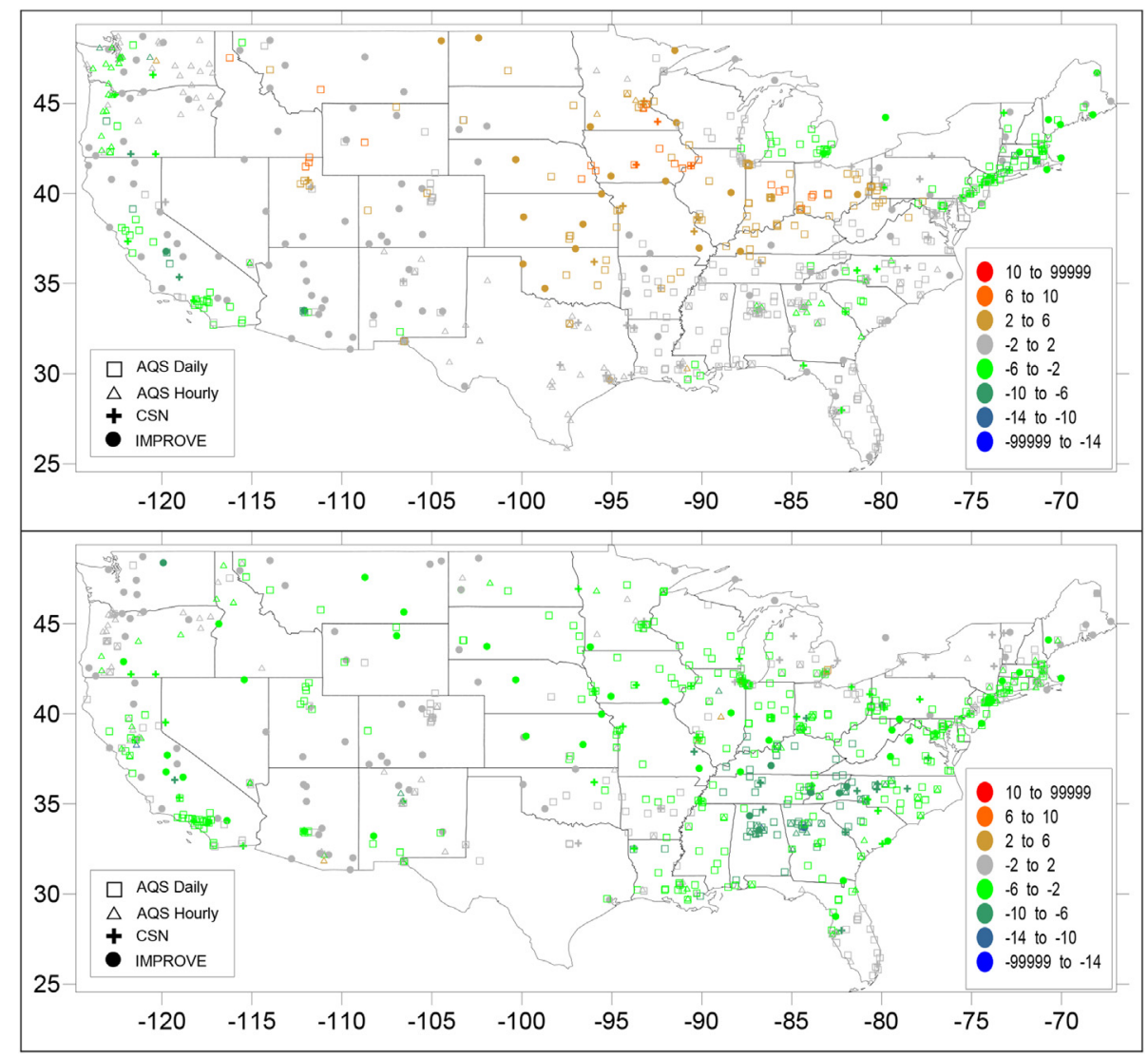

Fig. 7. Change (2010-2006) in seasonal mean $\mathrm{PM}_{2.5}\left(\mu \mathrm{g} / \mathrm{m}^{3}\right)$ during winter (top) and summer (bottom) at U.S. monitoring sites. 
occurred in the west. Note that fewer ozone monitoring sites operate during the winter as compared to the summer.

Summer and winter mean $\mathrm{SO}_{2}$ concentrations generally declined in the Northeast and upper Midwest between 2006 and 2010 with smaller reductions in the Southeast although increases were observed at isolated sites (Fig. 6). Many $\mathrm{SO}_{2}$ monitors are located near large sources and may thus be more influenced by emission changes occurring for a variety of reasons at the individual sources rather than at a region-wide level.

Summer mean $\mathrm{PM}_{2.5}$ concentrations decreased at many sites throughout the U.S. (Fig. 7). Of the sites shown having differences falling within $\pm 2 \mu \mathrm{g} / \mathrm{m}^{3}$, the sites in the Florida peninsula in particular (where African dust impacts are most noticeable) all showed negative differences, consistent with the IFS-MOZART simulation results (Fig. 4). Winter mean concentrations also decreased in the major urban areas in the Northeast, upper Midwest and the far west but increased or were largely unchanged elsewhere with increases most notable in central Ohio, central Indiana, Iowa, Minnesota, and a few locations in the Intermountain West. Annual 98th percentile daily maximum $\mathrm{PM}_{2.5}$ concentration (which is the design value referenced in U.S. EPA's NAAQS), showed a mixed pattern of increases and decreases, depending on local conditions (Fig. S2).

\subsection{Meteorological conditions}

Meteorological conditions during 2006 and 2010 differed markedly in both the winter and summer seasons. Winter surface temperatures were below normal in the Southeast and northern plains during 2010. In contrast, the winter of 2006 was generally warmer than average (Fig. 8). Wind speeds were also generally lower in the winter of 2010. Winter sea-level pressure patterns (Fig. 10) are consistent with greater northerly component winds during 2010 as compared to 2006 in the eastern U.S. and Canada. This enhanced flow out of the north is consistent with the negative temperature anomalies shown in Fig. 8. Winter precipitation patterns were generally similar in 2006 and 2010 but with more precipitation in California during 2006 (Fig. 11).

Summer surface temperatures were above normal and wind speeds were below normal in the eastern U.S. in 2010 as compared

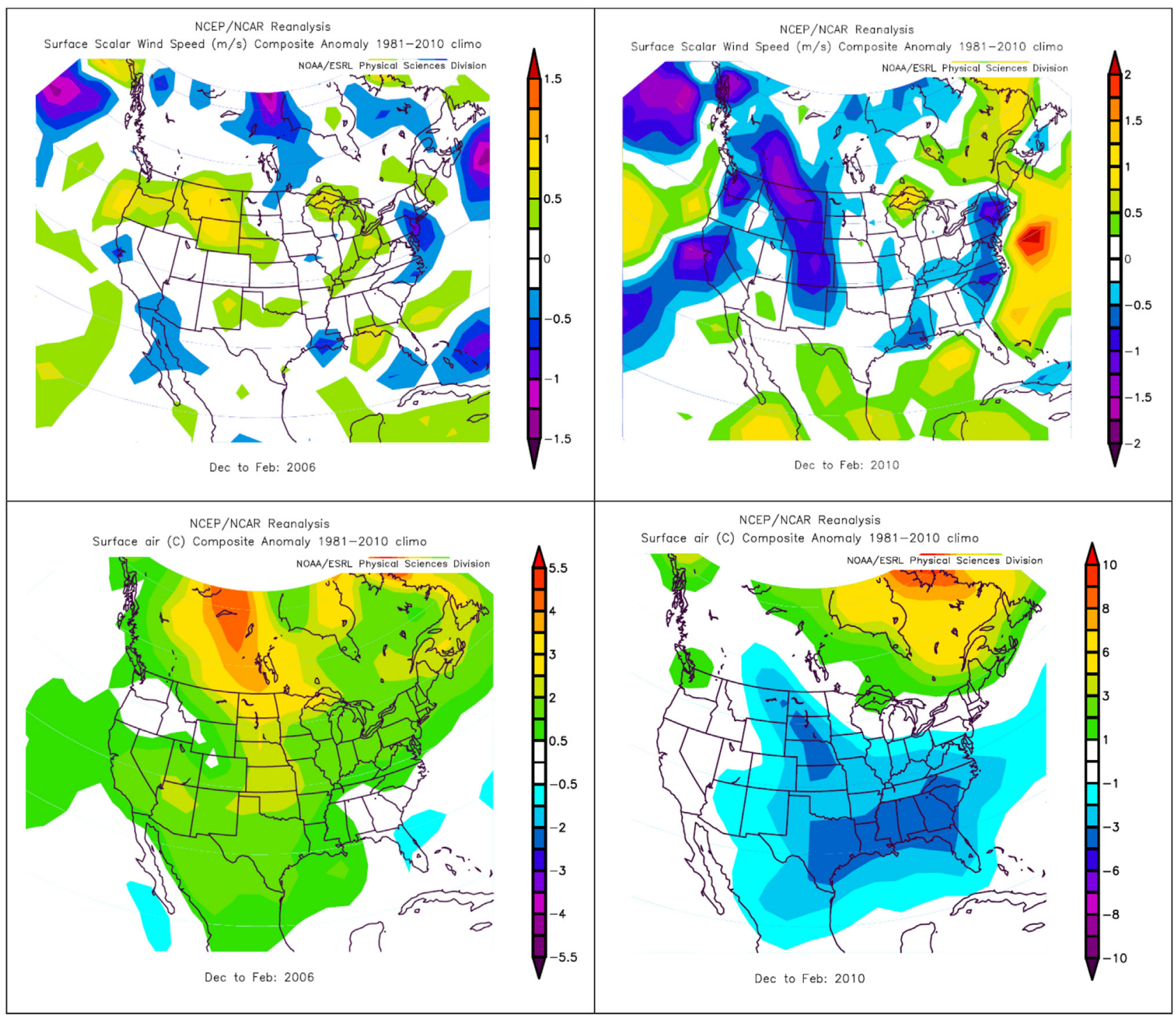

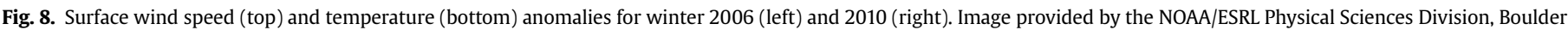
Colorado from their Web site at http://www.esrl.noaa.gov/psd/. 
to 2006 whereas most of the central and western US and Canada experienced above normal temperatures and near normal to below normal wind speeds in 2006 (Fig. 9). This pattern is consistent with a stronger surface pressure gradient between the pacific southwest high and thermal trough over the Southwest during the summer of 2010 (Fig. 10), which created stronger northwest flow along much of the west coast. Surface pressures were higher than average and pressure gradients less tight in the Southeast during summer 2006 as compared to 2010. Summer precipitation throughout much of the eastern U.S. and Canada was lower in 2010 as compared to 2006 (Fig. 11).

\section{Discussion}

Results presented in the previous section show the 2006 and 2010 differed substantially in terms of emissions, boundary conditions, meteorological conditions and observed air quality. Large reductions in $\mathrm{SO}_{2}$ and, to a lesser extent, $\mathrm{NO}_{\mathrm{x}}$ emissions in 2010 relative to 2006 would, in the absence of other factors, be expected to result in significant reductions in $\mathrm{SO}_{2}$ and sulfate and nitrate $\mathrm{PM}$ concentrations. $\mathrm{O}_{3}$ reductions would also be expected in at least some locations as a result of $\mathrm{NO}_{\mathrm{x}}$ and $\mathrm{VOC}$ emission reductions.
Factors potentially modulating these expected changes in ambient concentrations include the influences of large-scale background concentrations specified through boundary conditions, meteorology, and changes in the efficiency of secondary $\mathrm{PM}$ and $\mathrm{O}_{3}$ formation from precursor species via non-linear chemical reactions.

Meteorological conditions during 2010 differed in significant ways from 2006 as described in Sec. 3.4 and these differences can be expected to have influenced differences in ambient air quality. Stronger high pressure in the Southeast, warmer temperatures and below normal precipitation in the eastern U.S. and lower wind speeds along the East Coast during the summer of 2010 suggest greater stagnation and more favorable conditions for primary pollutant buildup and ozone formation throughout much of the East in 2010 as described below. During 2006 on the other hand, above normal temperatures and lower wind speeds prevailed in much of the central and western U.S., suggesting conditions potentially more favorable to ozone formation in these locations as compared to 2010. Colder temperatures and lighter average winds in the northern plains and southeast during winter 2010 as compared to 2006 are conducive to shallow mixing layers and reduced dispersion. These conditions may have contributed to the higher $\mathrm{SO}_{2}$ concentrations during the winter of 2010 seen at some

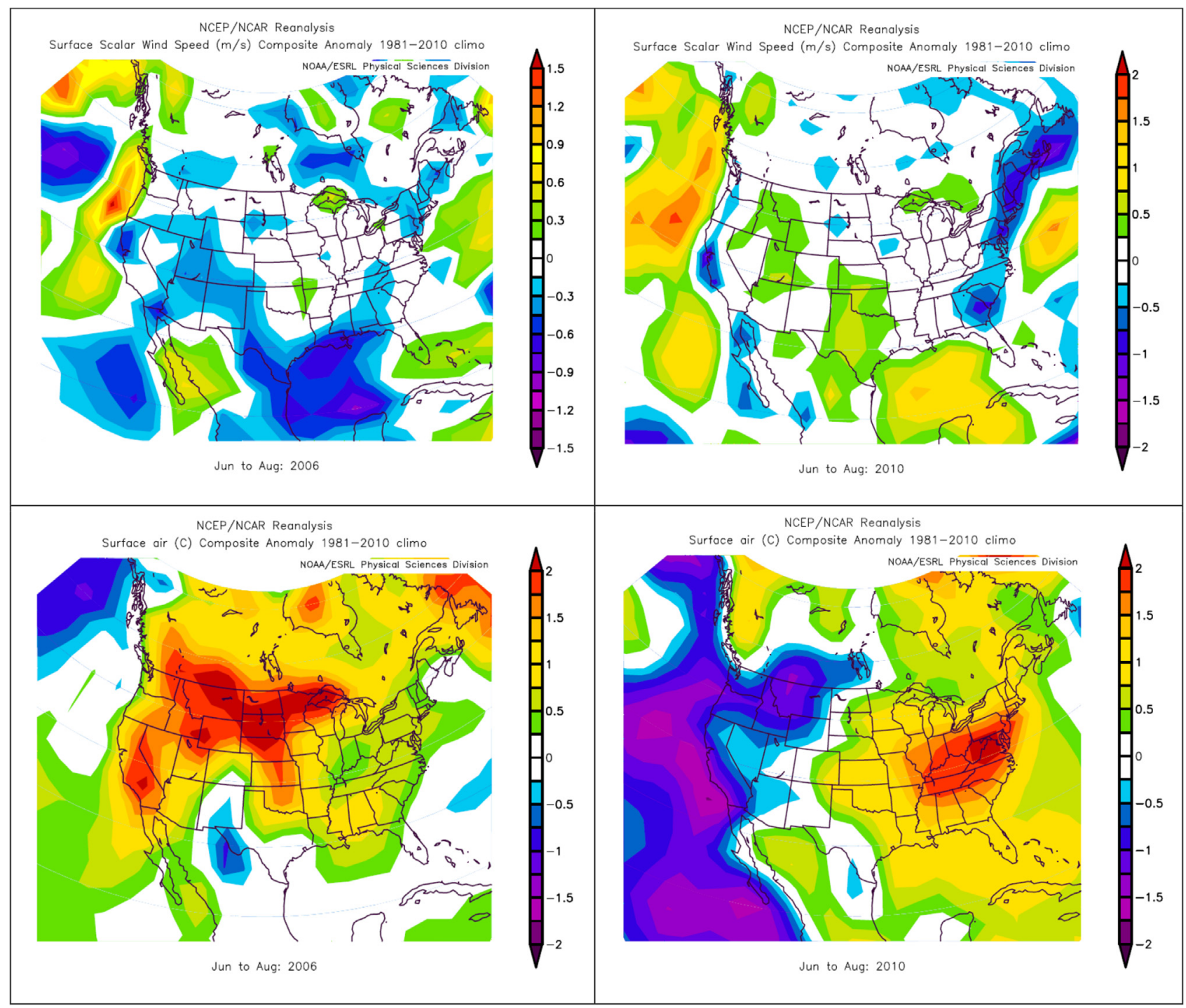

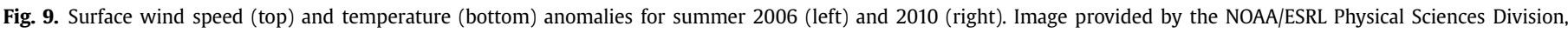
Boulder Colorado from their Web site at http://www.esrl.noaa.gov/psd/. 
monitors in these areas (Fig. 6). Enhanced precipitation along the California coast in the winter of 2010 is consistent with stormier weather and associated stronger mixing and marine air mass influence, suggesting a reduced occurrence of winter stagnation events and may have contributed to lower pollutant concentrations as see, for example, for PM2.5 (Fig. 7).

Lower IFS-MOZART predicted mid-tropospheric ozone in 2010 (Fig. 3) over inflow regions suggests lower BC ozone influx with concentrations as much as $10-20 \mathrm{ppb}$ lower during non-summer months and 5-10 ppb lower during the summer. However, observed surface ozone concentrations in the U.S. are not uniformly lower in either season. Factors influencing 2010-2006 ozone differences are discussed later in this section. IFS-MOZART midtropospheric fine dust and sulfate aerosol patterns described in Sec. 3.2 appear consistent with the observed stronger, more zonal mean $700 \mathrm{mb}$ flow producing more westward transport over the Pacific and looser $700 \mathrm{mb}$ height gradients over the Great Plains (consistent with less windblown dust) in 2010 (not shown). Differences in IFS-MOZART fine dust and sulfate aerosol patterns between 2006 and 2010 suggest BCs likely contributed $0.5-2 \mu \mathrm{g} / \mathrm{m}^{3}$ more fine PM during the spring (especially in the western U.S. and Canada) but summer PM levels in the interior West and eastern portions of the domain were likely driven lower by a similar size reductions in BC concentrations within the characteristic summer southwest monsoon in the West and prevailing southeasterly flow in the Southeast, respectively. Summer $\mathrm{PM}_{2.5}$ concentrations were lower at surface monitoring sites in both regions in 2010 although determining the degree to which the cleaner BCs contributed to this reduction will require further analysis.

Comparison of 2006-2010 changes in $\mathrm{SO}_{2}$ emissions (Fig. 1) and seasonal mean concentrations (Fig. 6) suggest there may be some mismatches between emission reductions and concentration reductions for this primary pollutant. Regional comparisons of $\mathrm{SO}_{2}$ reductions in the inventory with changes in sub-region average seasonal mean concentrations for winter and summer are shown in Fig. 12. As shown in Fig. 1, emissions in the Midwest, Northeast, and Southeast sub-regions are much larger than in other sub-regions so the comparisons in Fig. 12 are most useful for these three subregions; concentrations and relative changes in concentrations in the other sub-regions are likely influenced by outliers and emissions transported from upwind areas. During the summer, relative concentration reductions were roughly similar to the emission reductions. Concentration reductions during the winter were also similar to the emission reductions in the Midwest and Northeast. In

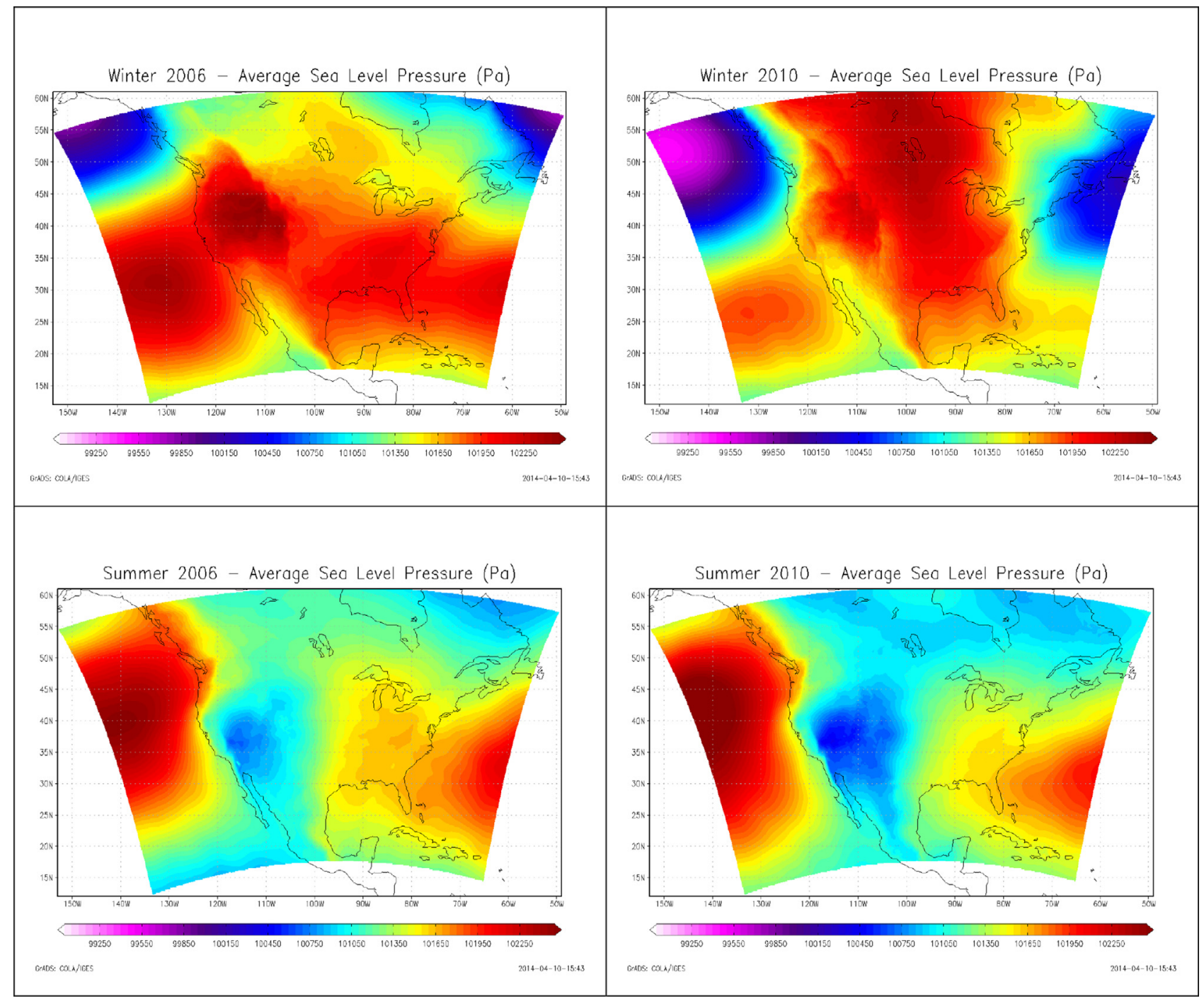

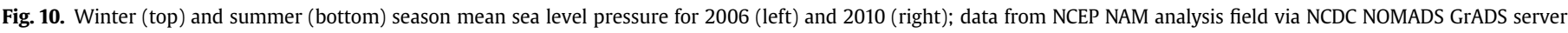
(http://nomads.ncdc.noaa.gov/dods/NCEP_NAM_ANALYSIS/Anl_Complete). 
the Southeast, however, the $45 \%$ reduction in emissions far exceeds the $16 \%$ reduction in average ambient concentration. Over $80 \%$ of the $\mathrm{SO}_{2}$ emissions in the Southeast for 2006 (and over 95\% of the 2006-2010 $\mathrm{SO}_{2}$ emission reductions) are attributed to CEMS sources where stack emissions are directly measured, so any errors in the emission totals are likely to be minor. Examination of the ambient monitoring data reveals large inter-site variability in $\mathrm{SO}_{2}$ trends, suggesting that intra-sub-regional differences in seasonal emission patterns coupled with the relatively sparse $\mathrm{SO}_{2}$ monitoring network could be responsible for the apparent inconsistency. Enhanced stagnation, consistent with the colder temperatures and lighter winds in the winter of 2010 (Fig. 8) may have further contributed to the less than expected reduction in $\mathrm{SO}_{2}$ concentrations. AQMEII-2 model performance results for $\mathrm{SO}_{2}$ should be examined closely for the Southeast region to verify if the emissions and ambient trends are actually consistent with each other.

Differences (2010-2006) in seasonal mean $\mathrm{PM}_{2.5}$ concentrations show spatial inhomogeneities during winter (Fig. 7) which appear inconsistent with reductions in $\mathrm{SO}_{2}$ and $\mathrm{NO}_{\mathrm{x}}$ emissions (Fig. 1). Seasonal mean $\mathrm{PM}_{2.5}$ speciation data calculated from observations collected at CSN and IMPROVE network monitoring sites as provided by Hogrefe et al. (2015) were examined to determine which PM species contributed to the different trends in winter mean $\mathrm{PM}_{2.5}$ in the Northeast, where $\mathrm{PM}_{2.5}$ mass was generally $2-6 \mu \mathrm{g} / \mathrm{m}^{3}$ lower in 2010 in both summer and winter, as compared to the Midwest where $\mathrm{PM}_{2.5}$ was higher in 2010 at most sites during the winter but lower during the summer. This analysis was restricted to 15 sites with valid data in both 2006 and 2010 in 5 Midwest states (IL, IN, IA, MN, OH) and 4 Northeastern states (MA, $\mathrm{NH}, \mathrm{RI}, \mathrm{VT}$ ). Results for elemental carbon (EC), $\mathrm{NH}_{4}, \mathrm{NO}_{3}$, organic carbon (OC), $\mathrm{SO}_{4}$, total carbon (TC), soil particles and other PM mass are summarized in Fig. 13 (see RTI, 2013 for details of data collection and analysis methods). Winter PM increases in the Midwest were found to be associated with a $60 \%$ increase in the average $\mathrm{NO}_{3}$ concentration and a $28 \%$ increase in the average $\mathrm{NH}_{4}$ concentration whereas $\mathrm{SO}_{4}$ declined slightly (5\%). Changes in the remaining species were smaller except for an average $14 \%$ reduction in unidentified ("Other") PM. However, valid values of Other PM were only available at 7 of the 15 monitoring sites where valid $\mathrm{NO}_{3}, \mathrm{SO}_{4}$ and $\mathrm{NH}_{4}$ differences could be calculated and may not be representative of average changes over the full 15 site network. In the Northeast, on the other hand, reductions were observed in all species during the winter. Changes in PM component species were similar between the two sub-regions during summer. Inspection of

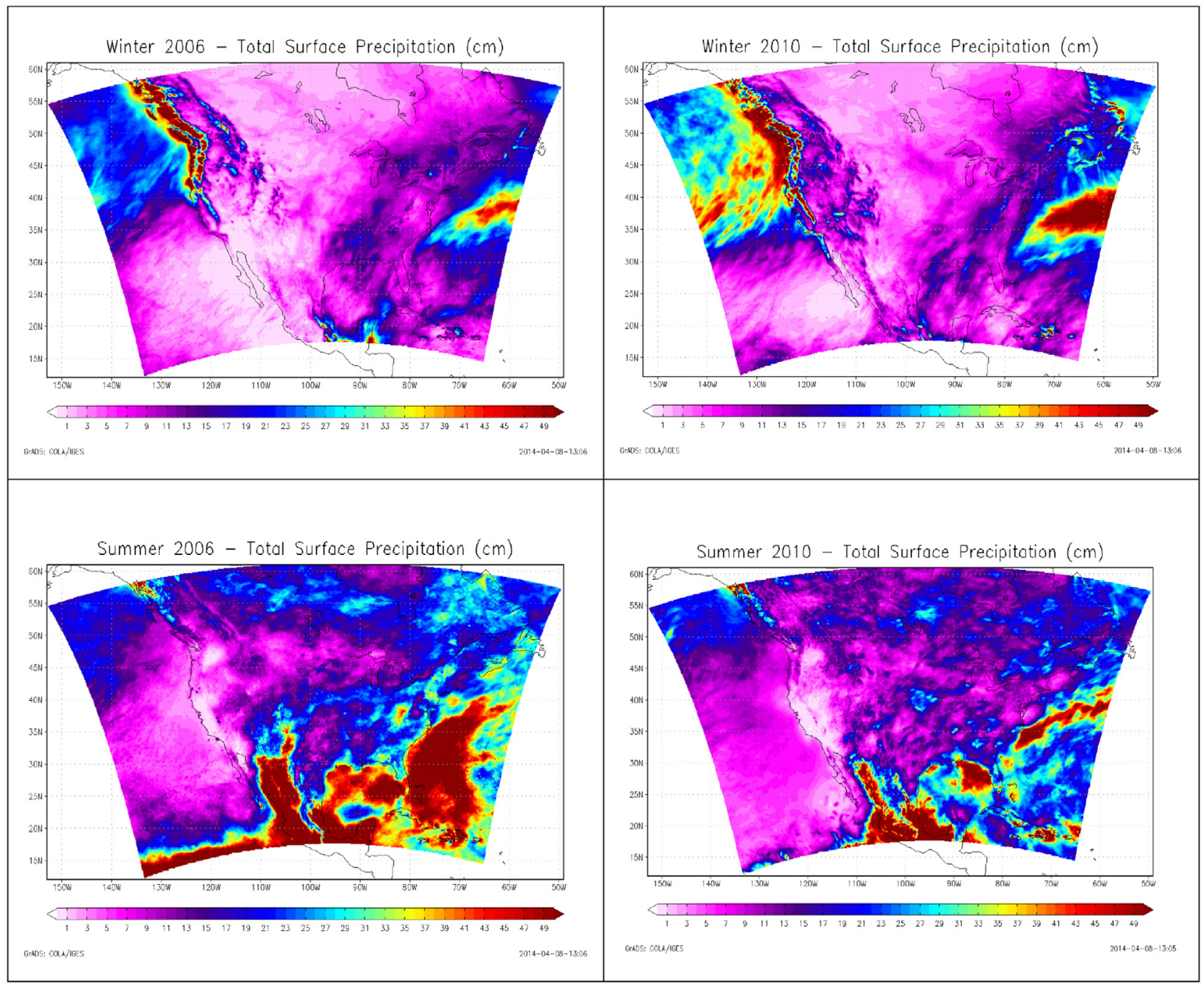

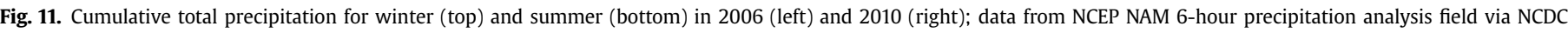
NOMADS GrADS server (http://nomads.ncdc.noaa.gov/dods/NCEP_NAM_ANALYSIS/6hr_Pcp). 

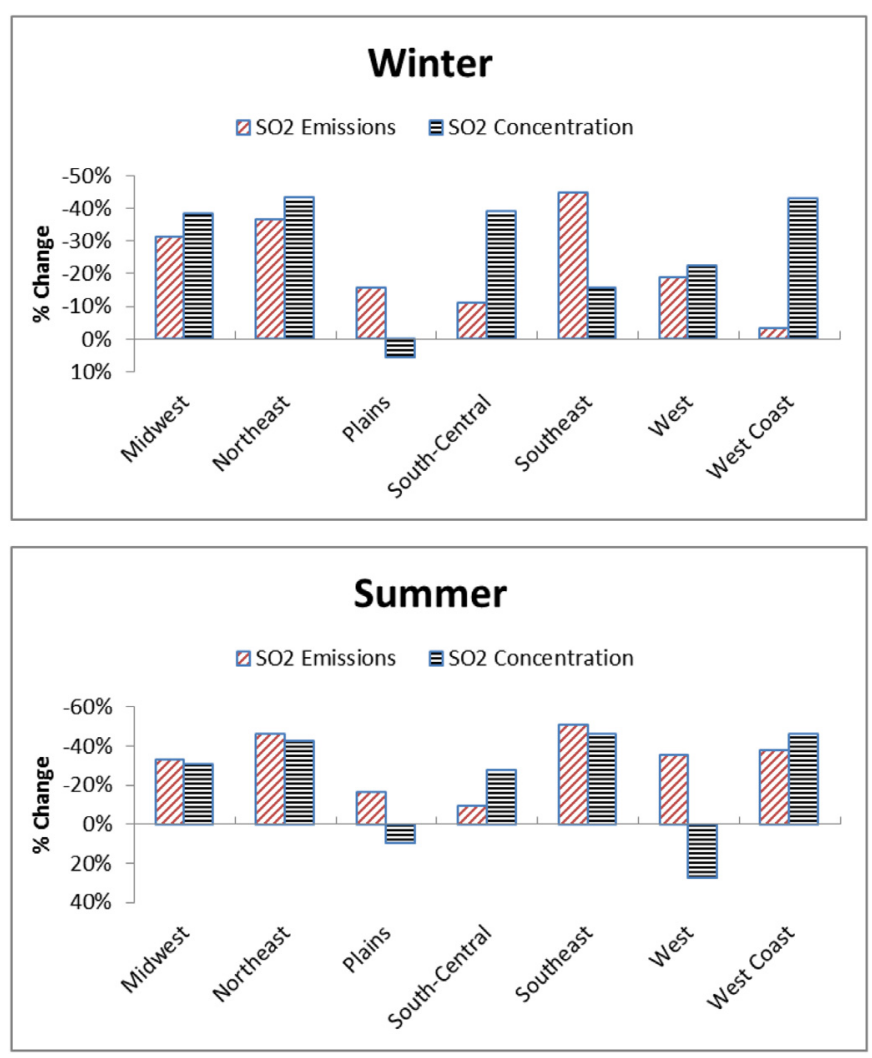

Fig. 12. Comparison of 2006-2010 sub-regional relative changes (2010/2006-1) in $\mathrm{SO}_{2}$ emissions and sub-regional average $\mathrm{SO}_{2}$ concentrations for winter (top) and summer (bottom).

seasonal mean species concentrations (Table 3 ) shows that summer particulate nitrate mass is low, consistent with greater partitioning of total $\mathrm{NO}_{3}$ as $\mathrm{HNO}_{3}$ under warmer temperatures.

The observed large, year round reductions in $\mathrm{SO}_{4}$ concentrations in the Northeast are consistent with the $\mathrm{SO}_{2}$ emission reductions shown in Fig. 1. A similar relationship is seen during summer in the Midwest but winter mean $\mathrm{SO}_{4}$ concentrations declined only slightly as noted above despite a $32 \%$ reduction in Midwest winter $\mathrm{SO}_{2}$ emissions. In contrast, reductions in winter mean $\mathrm{SO}_{2}$ concentrations in the Midwest (averaged over 82 sites with valid data in both years) are on par with the Midwest winter $\mathrm{SO}_{2}$ emission reductions (Fig. 12). Assuming $\mathrm{SO}_{4}$ neutralization was not limited by availability of free ammonia, particulate $\mathrm{SO}_{4}$ formation must have responded to factors which overrode the influence of lower $\mathrm{SO}_{2}$ emissions. In fact, 2010-2006 $\mathrm{SO}_{4}$ concentration differences ranged from $-32 \%$ to $+36 \%$ over the 15 monitoring sites included in this analysis, indicating a wide variation in $\mathrm{SO}_{4}$ formation efficiencies. The correlation between relative $\mathrm{SO}_{2}$ and $\mathrm{SO}_{4}$ changes at the 6 sites with co-located measurements is very poor $\left(\mathrm{R}^{2}<0.01\right)$, also indicating variable local influences of meteorological and chemical conditions on $\mathrm{SO}_{2}$ oxidation during winter. Winter $\mathrm{NO}_{\mathrm{x}}$ emissions decreased $30 \%$ in the Midwest (Table 1) while $\mathrm{NH}_{3}$ emissions were nearly unchanged in the modeling inventory. Particulate $\mathrm{NH}_{4}$ increased at all but one site and increases in $\mathrm{NO}_{3}$ are closely correlated with the increases in $\mathrm{NH}_{4}\left(\mathrm{r}^{2}=0.84\right)$ although the regression fit shows a $2.3 \mu \mathrm{g} / \mathrm{m}^{3}$ increase in $\mathrm{NO}_{3}$ for each $1 \mu \mathrm{g} /$ $\mathrm{m}^{3}$ increase in $\mathrm{NH}_{4}$, well below the $3.4: 1 \mathrm{NO}_{3} / \mathrm{NH}_{4}$ molar mass ratio for $\mathrm{NH}_{4} \mathrm{NO}_{3}$.

Stanier et al. (2012) studied winter $\mathrm{NO}_{3}$ episodes in Wisconsin and identified a relationship between elevated $\mathrm{NO}_{3}$, snow cover and near freezing temperatures which promote fog formation and stabilization of the boundary layer. While the causality chain resulting in the winter $\mathrm{NO}_{3}$ episodes remains uncertain, it is interesting to note that the 2009-2010 winter was exceptionally snowy in many parts of the eastern U.S., including the Midwest (NCDC, 2010), thus suggesting the conditions found by Stanier et al. to be favorable for elevated $\mathrm{NO}_{3}$ concentrations may have been more prevalent in 2010. The simple fact that colder temperatures prevailed during the 2010 winter may also have reduced $\mathrm{NO}_{3}$ volatilization relative to winter 2006. AQMEII-2 modeling results should be examined to determine if the 2010 upper Midwest particulate NO3 increase is reproduced in the simulations. Diagnostic analyses of model results may shed further light on the underlying causes of the winter NO3 increase.

Ozone concentration differences between 2010 and 2006 shown in Fig. 5 exhibit distinctive regional patterns resulting from a combination of ozone sensitivity to $\mathrm{NO}_{\mathrm{x}}$ emission reductions, boundary conditions, and meteorological conditions. Higher winter mean MDA8O3 in eastern urban areas in 2010 may be linked to reduced titration by NO - which is more of a controlling factor during winter-as a result of lower NOx emissions (Fig. 1). Mixed trends in winter ozone levels at rural locations (Fig. S4) suggest either that local conditions overwhelmed expected reductions from lower large-scale background ozone levels or that the IFS-MOZART predictions of lower background ozone in 2010 are not valid. During summer, the higher temperatures in most U.S. locations east of the Mississippi River and lower wind speeds along the East Coast in 2010 (Fig. 9) are consistent with conditions generally more favorable to ozone formation (NRC, 1991). As a result, any ozone reductions resulting from emission decreases or reductions in largescale background ozone in 2010 may have been masked by the more favorable meteorological conditions. BC influences during the summer peak ozone season in eastern North America are generally at a minimum in any case (EPA, 2013). Camalier et al. (2007) developed a generalized linear model (GLM) from historical data relating MDA8O3 in major U.S. cities to key meteorological parameters and used the fitted model to calculate adjusted multi-year trends in summer (May-September) mean MDA8O3 that compensate for year-to-year variations in meteorological conditions. Analysis of the GLM fits by Camalier et al. showed that a set of eight meteorological variables related to temperature, relative humidity, vertical stability and wind patterns are the most important variables associated with ozone at most locations. Model fits to MDA803 were best in eastern U.S. cities with weaker correlations in other U.S. cities. Adjustments calculated from the GLM model fits to the maximum MDA8O3 across the monitoring network in each U.S. city (based on Core-Based Statistical Areas or CBSAs as defined by the U.S. Census Bureau) and to the MDA8O3 at each rural site included in the CASTNET monitoring network have been computed by U.S. EPA (http://www.epa.gov/airtrends/weather.html). The adjusted values were calculated as the GLM model prediction of the May-September mean MDA803 concentrations after removing the variability due to meteorological effects (i.e., the GLM prediction when all daily meteorological parameter values for a given location are set equal to their long-term mean). The top row of Fig. 14 shows the magnitude of the meteorological adjustment for 2006 and 2010 (computed as difference between the unadjusted and adjusted seasonal mean MDA803 concentrations), positive values indicate regions where meteorological conditions increased ozone concentrations over what they would have been under more typical conditions while negative values indicate the opposite. The bottom row shows the difference in these adjustments between 2010 and 2006 with positive values indicating regions where the changes in meteorological conditions between 2006 and 2010 led to an ozone increase and vice versa. These results confirm the hypothesis that conditions more favorable for ozone formation occurred in 2010 as 


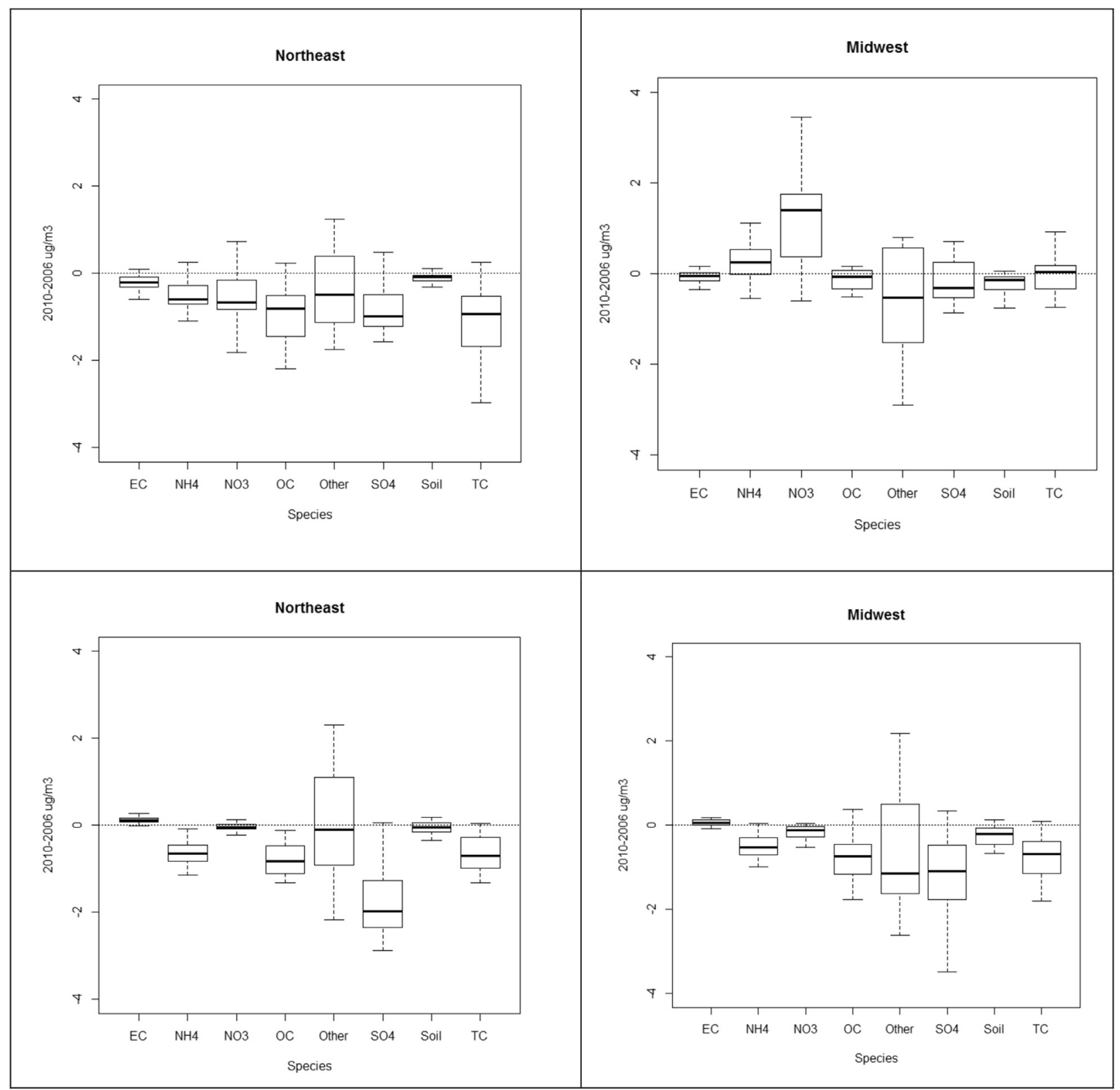

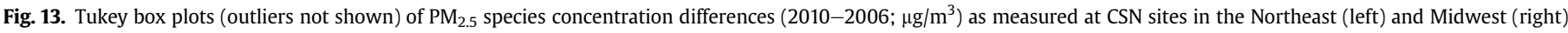
during winter (top) and summer (bottom).

compared to 2006 in the Northeast, Mid-Atlantic and Midwest regions with mostly near zero to -3 ppb adjustments elsewhere. Application of these meteorological adjustment factors to the 2006 and 2010 ozone data shows that ozone is lower in nearly all urban

Table 3

Winter and summer mean $\mathrm{SO}_{4}$ and $\mathrm{NO}_{3}$ concentrations $\left(\mu \mathrm{g} / \mathrm{m}^{3}\right)$ in 2006 and 2010 from CSN monitoring data for Northeastern states (Region 1) and five Midwestern states (Region 2) during winter and summer.

\begin{tabular}{|c|c|c|c|c|}
\hline \multirow[b]{2}{*}{ Region } & \multicolumn{2}{|l|}{$\mathrm{SO}_{4}$} & \multicolumn{2}{|l|}{$\mathrm{NO}_{3}$} \\
\hline & 2006 & 2010 & 2006 & 2010 \\
\hline & Winte & & & \\
\hline Northeast & 2.90 & 2.14 & 2.54 & 2.27 \\
\hline Midwest & $\begin{array}{l}2.57 \\
\text { Summ }\end{array}$ & 2.47 & 3.36 & 4.56 \\
\hline Northeast & 5.33 & 3.54 & 0.521 & 0.550 \\
\hline Midwest & 4.57 & 3.35 & 0.582 & 0.743 \\
\hline
\end{tabular}

areas throughout the U.S. in 2010 compared to 2006 after compensating for meteorological influences (Fig. 15), consistent with the lower $\mathrm{NO}_{\mathrm{x}}$ and $\mathrm{VOC}$ emissions noted in Sec. 3.1. Photochemical model results should be analyzed to verify that they reproduce this meteorological impact on predicted ozone trends.

\section{Summary and conclusions}

Several participants in the AQMEII-2 collaboration who are applying coupled models to the North American domain are comparing model results for two very different years: 2006 and 2010 (Campbell et al., 2015; Hogrefe et al., 2015; Wang et al., 2015). While the key differences of interest between these two years from a modeling perspective are the predicted air quality impacts of the large reductions in emissions of $\mathrm{NO}_{\mathrm{x}}(21 \%)$ and $\mathrm{SO}_{2}$ (36\%) which occurred mostly in the eastern U.S. and the lower emissions from wildfires in the western U.S., meteorological conditions and model 

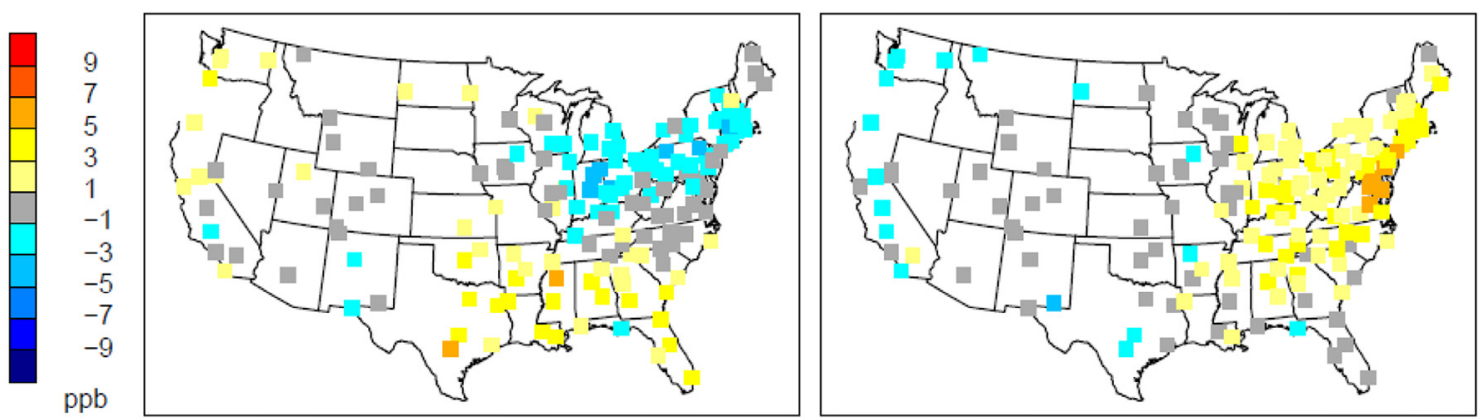

2010-2006 Change Due to Met ((2010 raw - 2010 adj)-(2006 raw - 2006 adj $))$

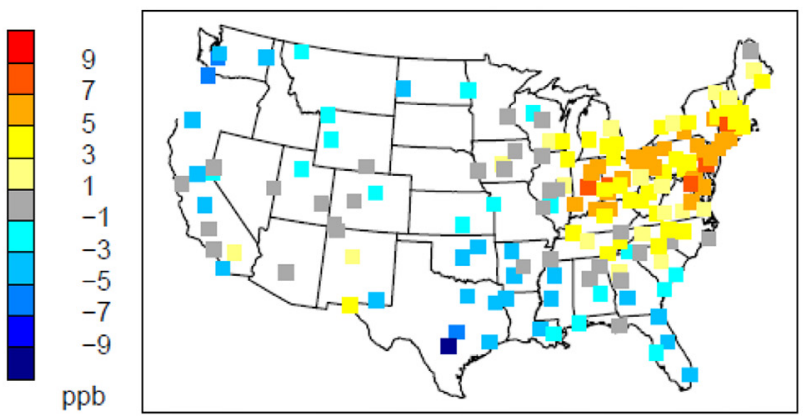

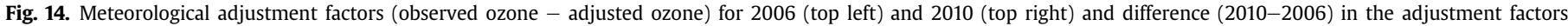
(bottom) as applied to May-September mean MDA803 ozone.

boundary conditions (BCs) also differed significantly between these two years. Differences in meteorological conditions both confound the impact of emission reductions on ambient air quality and provide an opportunity to examine how models respond to changing meteorology. Similarly, the contribution of differences in pollutant fluxes into North America to observed and simulated air quality also need to be taken into account. To provide information needed to put model results in perspective and aid AQMEII-2 modeling groups with their evaluations of model performance, we undertook a comparison of emissions, large-scale background concentrations simulated by a global model used to specify BCs for the AQMEII-2 regional models, and observed air quality and meteorological conditions between the two modeled years. Results of our analysis showed that significant differences are evident in observed air quality between 2006 and 2010 based on data collected at U.S. monitoring sites and that meteorological variations and potentially changes in large-scale background concentrations can mask the expected influence of emission reductions in some cases.

Meteorological conditions in 2010 differed from 2006 in a number of ways, including higher summer surface temperatures in the eastern U.S. Summer precipitation throughout much of the eastern U.S. and Canada was lower in 2010 which may have reduced the benefits of emission reductions. Winter mean surface temperatures were generally above average in 2006, whereas in 2010, below average temperatures were noted in the Southeast and northern plains, consistent with a greater frequency of cold arctic air outbreaks.

Despite the reductions in anthropogenic ozone precursor emissions, changes in summer mean and annual 4th highest daily maximum 8-hour average ozone concentrations were limited to $\pm 2 \mathrm{ppb}$ in many parts of the Northeast and Midwest although larger
2010 - 2006, Raw
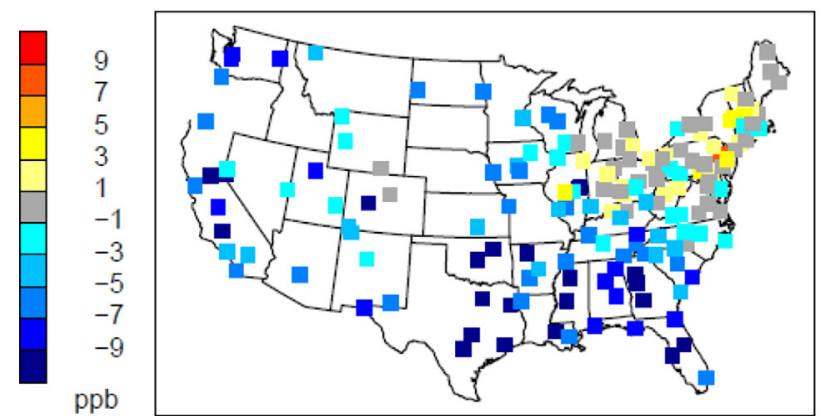

2010 - 2006, Adjusted

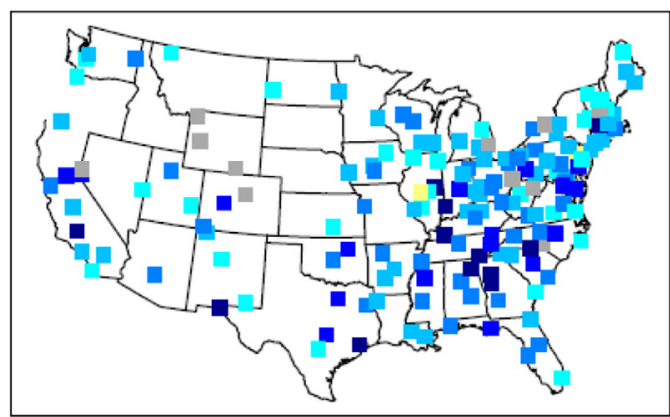

Fig. 15. Unadjusted (left) and meteorologically adjusted (right) change (2010-2006) in U.S. urban area May-September mean MDA803. 
reductions were found in the Southeast. Inter-annual comparisons of meteorological factors known to influence ozone levels suggested that conditions, including higher temperatures in the eastern U.S., were more favorable for ozone production in 2010, largely masking the influence of reduced emissions. Removing the influence of these differences in meteorological conditions using the regression model developed by Camalier et al. (2007) confirmed that ozone would have been lower in 2010 than in 2006 if meteorological conditions had been similar during the two summers.

A marked seasonal difference in ambient $\mathrm{PM}_{2.5}$ concentration changes between 2006 and 2010 was noted with winter mean concentrations higher in 2010 at many locations and particularly in the Midwest despite lower emissions of $\mathrm{SO}_{2}$ and $\mathrm{NO}_{\mathrm{x}}$ and little change in primary $\mathrm{PM}, \mathrm{NH}_{3}$ or anthropogenic VOC emissions. In contrast, summer $\mathrm{PM}_{2.5}$ concentrations were lower throughout most of the U.S. in 2010 with reductions in the western U.S. likely due in part to the large reduction in wildfires. The Midwestern winter $\mathrm{PM}_{2.5}$ increases appear to have been primarily driven by higher particulate $\mathrm{NO}_{3}$ levels, the underlying cause of which are not immediately apparent and will require further analysis.

Reductions in ambient $\mathrm{SO}_{2}$ concentrations consistent with reductions in $\mathrm{SO}_{2}$ emissions were found to have occurred during both summer and winter in two of the three U.S. sub-regions with significant $\mathrm{SO}_{2}$ emissions (the Northeast and Midwest) and also during the summer in the Southeast sub-region. However, the reported $22 \%$ reduction in winter $\mathrm{SO}_{2}$ emissions in the Southeast were not accompanied by corresponding reductions in ambient $\mathrm{SO}_{2}$ levels. Meteorological conditions conducive to greater stagnation and primary pollutant buildup in 2010 may partially explain the discrepancy but it is also possible that intra-sub-regional differences in seasonal emission patterns coupled with the relatively sparse $\mathrm{SO}_{2}$ monitoring network could have led to a spurious result. AQMEII-2 model performance results for $\mathrm{SO}_{2}$ should be examined closely for the Southeast region to verify if the emissions and ambient trends are actually consistent with each other.

Comparison of 2006 and 2010 global simulations used to specify BCs for the AQMEII-2 simulations showed lower seasonal mean ozone concentrations in 2010 although the differences were relatively small during the summer when ozone production is at a maximum, thus suggesting limited BC influences on peak ozone. Observed 2010-2006 differences in winter mean ozone varied from positive to negative across the U.S. even at rural sites, raising the possibility that the broad background ozone reductions predicted by IFS-MOZART are not realistic. AQMEII-2 model performance for ozone at rural sites during winter and spring should be closely examined to see if a bias is being introduced by lower BCs derived from IFS-MOZART. There are indications of enhanced fine dust and sulfate aerosol transport eastward across the Pacific during spring and enhanced fine dust transport westward across the subtropical Atlantic during winter and spring in 2010 but summer and fall dust transport across the subtropical Atlantic was reduced in 2010. The reduced summer African dust transport is quantitatively consistent with observed PM2.5 reductions in Florida.

In general, differences in emissions from U.S. sources and meteorological conditions during 2006 and 2010 in North America appear to be consistent with changes in observed air quality at U.S. monitoring sites except as noted above. Changes in emissions, BCs and differences in meteorological conditions between these two years provide an informative test case for examination of regional coupled model performance under changing conditions. Two potential inconsistencies (higher 2010 winter $\mathrm{PM}_{2.5}$ in the Midwest and lower than expected winter $\mathrm{SO}_{2}$ reductions in the Southeast) were noted which warrant further investigation via targeted model performance analyses by the AQMEII-2 community.

\section{Acknowledgments and disclaimer}

This study was supported by Coordinating Research Council Atmospheric Impacts Committee (CRC Project A-87). The authors thank George Pouliot for providing the emissions data. The views expressed here are those of the authors and do not necessarily reflect the views and policies of the U.S. Environmental Protection Agency (EPA) or any other organization participating in the AQMEII project. This paper has been subjected to EPA review and approved for publication.

\section{Appendix A. Supplementary data}

Supplementary data related to this article can be found at http:// dx.doi.org/10.1016/j.atmosenv.2015.02.043.

\section{References}

Camalier, L., Cox, W., Dolwick, P., 2007. The effects of meteorology on ozone in urban areas and their use in assessing ozone trends. Atmos. Environ. 41, 7127-7137.

Campbell, P., Yahya, K., Wang, K., Zhang, Y., Hogrefe, C., Pouliot, G., San Jose, R., Makar, P., 2015. A Multi-Model Assessment for the 2006 and 2010 Simulations under the Air Quality Model Evaluation International Initiative (AQMEII) Phase 2 over North America: Part I. Indicators of the Sensitivity of 03 and PM2.5 Formation Regimes. Atmos. Environ. 115, 569-586.

Dennis, R., Fox, T., Fuentes, M., Gilliland, A., Hanna, S., Hogrefe, C., Irwin, J., Rao, S.T., Scheffe, R., Schere, K., Steyn, D., Venketram, A., 2010. A framework for evaluating regional-scale numerical photochemical modeling systems. Environ. Fluid Mech. (Dordr.) 10 (4), 471-489.

EPA, February 2013. Integrated Science Assessment for Ozone and Related Photochemical Oxidants. EPA 600/R-10/076F. U.S. Environmental Protection Agency, Research Triangle Park, NC.

Galmarini, S., Rao, S.T., 2011. The AQMEII two-continent regional air quality model evaluation study: fueling ideas with unprecedented data. Atmos. Environ. 45, 2464.

Galmarini, S., Rao, S.T., Steyn, D.G., 2012. Preface to the special issue: AQMEII: an international initiative for the evaluation of regional-scale air quality models phase 1. Atmos. Environ. 53, 1-3.

Giordano, L., Brunner, D., Flemming, J., Im, U., Hogrefe, C., Bianconi, R., Badia, A. Balzarini, A., Baro, R., Chemel, C., Curci, G., Forkel, R., Jimenez-Guerrero, P. Hirtl, M., Hodzic, A., Honzak, L., Jorba, O., Knote, C., Kuenen, J.J.P., Makar, P.A., Manders-Groot, A., Neal, L., Perez, J.L., Pirovano, G., Pouliot, G., San Jose, R., Savage, N., Schroder, W., Sokhi, R.S., Syrakov, D., Torian, A., Werhahn, J., Wolke, R., Yahya, K., Zabkar, R., Zhang, Y., Galmarini, S., 2015. Assessment of the MACC reanalysis and its influence as chemical boundary conditions for regional air quality modeling in AQMEII-2. Atmos. Environ. 115, 371-388.

Hogrefe, C., Pouliot, G., Wong, D., Torian, A., Roselle, S., Pleim, J., Mathur, R., 2015 Annual application and evaluation of the online coupled WRF-CMAQ system over North America under AQMEII phase 2. Atmos. Environ. 115, 683-694.

Inness, A., Baier, F., Benedetti, A., Bouarar, I., Chabrillat, S., Clark, H., Clerbaux, C., Coheur, P., Engelen, R.J., Errera, Q., Flemming, J., George, M., Granier, C., HadjiLazaro, J., Huijnen, V., Hurtmans, D., Jones, L., Kaiser, J.W., Kapsomenakis, J., Lefever, K., Leitão, J., Razinger, M., Richter, A., Schultz, M.G., Simmons, A.J. Suttie, M., Stein, O., Thépaut, J.N., Thouret, V., Vrekoussis, M., Zerefos, C., the MACC team, 2013. The MACC reanalysis: an $8 \mathrm{yr}$ data set of atmospheric composition. Atmos. Chem. Phys. 13, 4073-4109. http://dx.doi.org/10.5194/acp13-4073-2013.

Kalnay, E., Kanamitsu, M., Kistler, R., Collins, W., Deaven, D., Gandin, L., Iredell, M., Saha, S., White, G., Woollen, J., Zhu, Y., Leetmaa, A., Reynolds, R., Chelliah, M., Ebisuzaki, W., Higgins, W., Janowiak, J., Mo, K.C., Ropelewski, C., Wang, J., Roy Jenne, Dennis Joseph, 1996. The NCEP/NCAR 40-Year Reanalysis Project. Bull. Am. Meteorol. Soc. 77, 437-471. http://dx.doi.org/10.1175/1520-0477(1996)077.

NIFC, 2014. Total Wildland Fires and Acres. National Interagency Fire Center. http:// www.nifc.gov/fireInfo/fireInfo_stats_totalFires.html (accessed 01.05.14.).

NCDC, 2010. "2009-2010 Cold Season"; National Climatic Data Center. National Oceanic and Atmospheric Administration, Asheville, NC. http://www.ncdc.noaa. gov/extremeevents/speciaslreports/2009-2010-Cold-Season.pdf.

NRC, 1991. Rethinking the Ozone Problem in Urban and Regional Air Pollution. National Research Council, Washington DC.

Pouliot, G., Denier van der Gon, H., Kuenen, J., Makar, P., Moran, M., Zhang, J., 2015 Analysis of the emission inventories and model-ready emission datasets of Europe and North America for phase 2 of the AQMEII project. Atmos. Environ. $115,345-360$.

RTI, 1 July 2013. Annual Data Summary Report for the Chemical Speciation of $\mathrm{PM}_{2.5}$ Filter Samples Project. RTI/0212053/04ADS. Research Triangle Institute, Research Triangle Park, NC. http://www.epa.gov/ttnamti1/files/ambient/pm25/ spec/2012ADSReport.pdf.

Rutledge, G.K., Alpert, J., Ebuisaki, W., 2006. NOMADS: a climate and weather model 
archive at the national oceanic and atmospheric administration. Bull. Am. Meteorol. Soc. 87, 327-341. http://nomads.ncdc.noaa.gov/dods/NCEP_NAM ANALYSIS/Anl_Complete.

Stanier, C., Singh, A., Adamski, W., Baek, J., Caughey, M., Carmichael, G., Edgerton, E., Kenski, D., Koerber, M., Oleson, J., Rohlf, T., Lee, S.R., Riemer, N., Shaw, S. Sousan, S., Spak, S.N., 2012. Overview of the LADCO winter nitrate study: hourly ammonia, nitric acid and PM2.5 composition at an urban and rural site pair during PM2.5 episodes in the US Great Lakes region. Atmos. Chem. Phys. 12, $11037-11056$.
Schere, et al., 2012. Trace gas/aerosol concentrations and their impacts on continental-scale AOMEII modelling sub-regions. Atmos. Environ. 53, 38-50.

Wang, K., Yahya, K., Zhang, Y., Hogrefe, C., Pouliot, G., Knote, C., Hodzic, A., San Jose, R., Perez, J.L., Guerrero, P.J., Baro, R., Makar, P., 2015. Evaluation of column variable predictions using satellite data over the continental United States: a multi-model assessment for the 2006 and 2010 simulations under the Air Quality Model Evaluation International Initiative (AQMEII) phase 2. Atmos. Environ. 115, 587-603. 